\title{
Is Human Trafficking an Issue in America's Backyards?
}

\author{
Barry Goodson* \\ Columbia Southern University, USA
}

Submission: January 27, 2017; Published: February 02, 2017

*Corresponding author: Barry Goodson, Columbia Southern University, USA, Tel: 817-458-1539; Email: Barry.Goodson@columbiasouthern.edu

\section{Introduction}

Hello, my name is Barry Goodson and I serve as a Professor of Criminal Justice with Columbia Southern University. My experience ranges from serving with a Special Ops group known as the CAP Marines during the Vietnam War to service in law enforcement as a member of the CAC Investigation Task Force, which involved many cases concerning local human trafficking, which is typically heralded as a crime that only happens overseas. My purpose for this article is to further awareness of this crime in our very backyards. One of the more memorable cases I worked involved a 13-year-old girl, who lived in the northern part of our county. Her parents were far from wealthy, dictating both parents work, leaving the child home alone many hours of each day. Sound familiar? According to E.J. Dionne, Jr. of the Washington Post [1], "most families these days cannot afford to have one parent stay home with the kids". This was the case with this family. Additionally, as our children reach the age of puberty, which may be one of the most emotional and more vulnerable stages in life, we, as parents, seem to believe that our children can automatically assume responsibility for their lives and that they will make the right decisions in any given situation, which is a task that remains formidable for most adults.

Our children then become what we commonly refer to as latchkey kids. "Overall, the number of self-supervised children has jumped to 15.1 million nationwide, a 6 percent increase since 2004. And, amazingly, it affects all income levels" [2]. This juvenile runaway was no exception to this rule. Additionally, her parents allowed unlimited access to the Internet, which evolved into constant participation in online chat rooms, which many know include adult predators who await their next victim...a lonely, latchkey kid. Even though a small percentage of our youth may use chat rooms on a regular basis, the fact remains that predators rely heavily on such tools to locate and entice their next victim [3]. Therefore, it was no surprise to discover, following an interview of this young girl's best friend that she had been enticed to meet the alleged mother of another frustrated, teenage girl at 2:00 AM one morning, while her parents quietly slept with assurance that their children were tucked safely away in their own beds.

These parents were obviously completely out of touch with their daughter to the degree that they did not even understand the severity of or the existence of her desire to run away from home. The strange vehicle rolled up around 2:00 AM as promised. The girl was already waiting for the car and knew the description of the vehicle and the mother based on the information she received online. She walked up to the car somewhat apprehensive, but recognized that the driver fit the description she has received online. However, the other girl was not in the car, which alarmed the run away, but the missing daughter was easily explained away by the reality that she was already in her own home asleep. The woman assured the girl that she would meet her new friend in the morning. The young, teenage girl stepped into the car and accepted a soft drink from the alleged mother, which was laced with a drug believed to have been rohypnol. Within moments the trusting girl fell silently under control of the drug given to her by the woman who had picked her up in the dark of night guised as the mother of the other teenager.

I met with the school principal and asked to see the missing girl's best friend. The girl entered the office and shared other friends that she knew but immediately confirmed that the girl had been chatting with another girl online. The only workable clue the friend offered stemmed from the fact that the alleged girl on the chat line said she lived in Hurst, Texas, which was about an hour east of our location. I launched a crusade in the Hurst, Euless, Bedford area that the girl's best friend had assured me was the destination of the victim's new home, which was in an adjacent, major county, which boasts a massive list of runaways on any given day. Would anyone pay any attention to another homeless teenager in such counties? Doubtful. Regardless, I left a flyer with each law enforcement agency in the area along with my calling card and asked them to ask their patrol officers to watch for the girl. As suspected, since the parents only listed the girl as a runaway, the agencies were not empowered to activate 
the Amber Alert in her behalf and the information I had was far from evidence of a kidnapping.

I refused to accept the runaway theory based on the fact that the girl had been enticed through the Internet. Using information and a photo provided by the parents, I created hundreds of fliers boasting the girl's photo; drove to the general area of the girl's alleged location and began a search from door-to-door; leaving a photo flier with each resident and apartment complex manager. After two days of knocking on doors, the effort paid off. One of the local police departments in the area contacted me to advise that an unknown individual driving a dark colored panel van had literally dumped the girl in a drug-induced state on the front lawn of the agency. The vehicle sped away before anyone realized what was happening and no camera or witnesses existed to aid in identifying the suspect vehicle. Therefore, we had very little to help us proceed with the investigation to the point of probable cause against an identified suspect. I wanted to pursue kidnapping charges and attempt to hunt the perpetrator down through a forensics analysis of the family computer, but the parents were only interested in recovering the girl and would not participate in further investigative efforts. The girl could offer no assistance either with the exception to the fact that she had been kept overnight in a hotel; she felt was in the general vicinity. Regardless, one child was saved from the clutches of another pedophile or prostitution ring.

Should we as parents and professionals remain cognitive of our children's actions that may lead to such dangers in their future...without a doubt? As mentioned by Peggy Bird of the Denver Post [4], many such victims consist of juvenile runaways and homeless children and the situation has become a national issue. Many states, such as Colorado have stepped forward with laws and actions that will enhance public awareness and enable our criminal justice system to properly prosecute those who prey upon the most innocent people in our world...our children. Human trafficking has evolved to being a major crime worldwide. Only efforts through organizations such as the Human Trafficking Investigations and Training Institute, which provides advanced human trafficking investigations strategies and techniques to law enforcement agencies nationwide as well as awareness training to all major NGOs (Non-Government Organizations) can we hope to bring this heinous crime under control [5].

\section{References}

1. EJ Dionne (2012) Two-Paycheck Couples Working Because They Must Washington Post, USA.

2. Jenny Deam (2014) The New Latchkey Kid. Parents magazine, USA.

3. Internetsafety101.org. (2013) Predator Statistics. USA.

4. Peggy Nelson Byrd (2013) Human Trafficking; Not In Colorado? The Denver Post, USA

5. HTITI (2017) Human Trafficking Investigations \& Training Institute, USA.

\section{Your next submission with Juniper Publishers} will reach you the below assets

- Quality Editorial service

- Swift Peer Review

- Reprints availability

- E-prints Service

- Manuscript Podcast for convenient understanding

- Global attainment for your research

- Manuscript accessibility in different formats

( Pdf, E-pub, Full Text, Audio)

- Unceasing customer service

Track the below URL for one-step submission https://juniperpublishers.com/online-submission.php 